ABCD Arq Bras Cir Dig

2019;32(2):e1445

DOI: /10.1590/0102-672020180001e1445

\section{ENDOSCOPIC REMOVAL OF AN UNUSUAL FOREIGN BODY FROM STOMACH: A WRISTWATCH}

\author{
Remoção endoscópıca de um corpo estranho exclusıvo do \\ estômago: um relógı de pulso
}

Omer Faruk OZKAN ${ }^{1}$, Sukru TAS ${ }^{1}$, Erdem AKBAL ${ }^{2}$

How to cite this article: Ozkan OF, Tas S, Akbal E. Endoscopic removal of an unusual foreign body from stomach: a wristwatch. ABCD Arq Bras Cir Dig. 2019;32(2):e1445. DOI: /10.1590/0102-672020180001e1445

From the ${ }^{1}$ Canakkale 18 March University, Faculty of Medicine, Department of General Surgery; ${ }^{2}$ Canakkale 18 March University, Faculty of Medicine, Departmentof Gastroenterology, Canakkale, Turkey

\section{Correspondence:}

Omer F. Ozkan

Email: ozkanfomer@gmail.com

HEADINGS - Endoscopy, Foreign Bodies, Stomach

DESCRITORES - Endoscopia, Corpos Estranhos, Estômago.

Financial source: none

Conflict of interest: none

Received for publication: 01/06/2017

Accepted for publication: 06/02/2019

\section{INTRODUCTION}

$\mathrm{F}$ oreign body ingestion is an important problem in adult with psychological disorders. In literature ingestion such as fish bone, fork and several metallic elements were reported. The first attempt, after diagnosis, is endoscopic removal'. Surgical approach is necessary in it's failure. In this paper is presented a successful endoscopic removal of a wristwatch which was ingested by a deaf patient.

\section{CASE REPORT}

A 25-year-old male deaf patient was admitted in emergency department with complaint of abdominal pain and unable to communicate anything of his clinical history. Physical examination was normal except an epigastric tenderness. Laboratory results were normal. Direct radiography revealed a circular shaped metallic object in stomach and other several metallic objects in gastrointestinal tract (Figure 1A). An emergent gastrointestinal endoscopy was planned and during the procedure a wristwatch in the stomach was diagnosed and successfully removed with an esophageal overtube approach under direct endoscopic vision (Figure 1B).
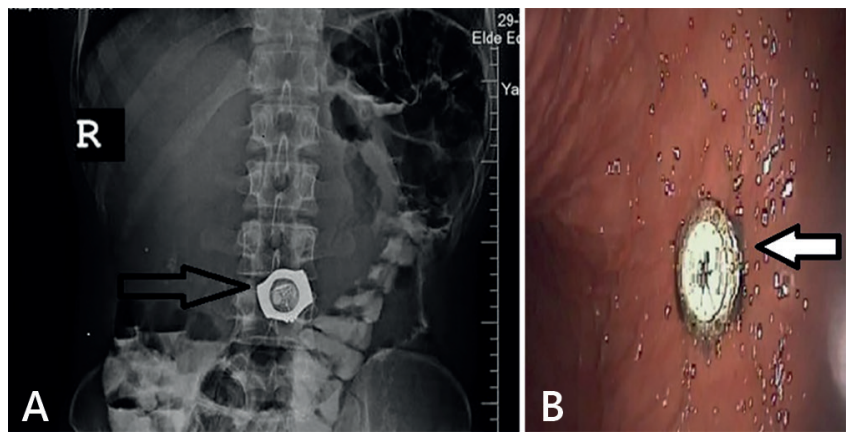

FIGURE 1 - A) Abdominal plain graph was showed a watch; B) endoscopic image of the watch in the stomach

\section{DISCUSSION}

A delay in the diagnosis an dextraction of sharp or large sized foreign objects can lead to severe complications including mucosal laceration, obstruction, hemorrhage, and perforation. Therapeutic esophagogastroduodenoscopy with an esophageal overtube should be the first choice retrieval of large sized foreign bodies to avoid mucosal laceration, perforation and the surgical treatment.

\section{ORCID}

Omer F. Ozkan: 0000-0002-6644-2413

\section{REFERENCES}

1. Goh YM, Shapey IM, Riyad K. Gastric perforation secondary to ingestion of a plastic bag. Ann R Coll Surg Engl.2016 Feb;98(2):e29-30.

2. Ikenberry SO, Jue TL, Anderson MA, et al. Management of ingested foreign bodies and food impactions. Gastrointest Endosc 2011;73: 1085-9.

3. Li ZS, Sun ZX, Zou DW, et al. Endoscopic management of foreign bodies in theupper-Gl tract: experiencewith 1088 cases in China. Gastrointest Endosc 2006;64:485-92. 